\title{
Regionalna inicijativa za migracije, azil i izbjeglice (MARRI)
}

DOI: https://doi.org/10.11567/met.33.3.5

\section{Tea Vinković}

Zagreb

Republika Hrvatska sudjeluje u brojnim regionalnim organizacijama i inicijativama na jugoistoku Europe. Jedna je od takvih inicijativa i Regionalna inicijativa za migracije, azil i izbjeglice (The Migration, Asylum, Refugees Regional Initiative, MARRI). Hrvatska se uglavnom udružuje sa zemljama iz srednjoeuropskoga, mediteranskog i podunavskog okruženja (većinom susjedne i bliže zemlje) (Tuđman i Ljubičić, 2007: 38). Većini tih inicijativa i organizacija cilj je jačanje regionalne suradnje, stvaranje klime povjerenja, dobrosusjedskih odnosa i stabilnosti te realizacija zajedničkih projekata za razvoj jugoistočne Europe. »Inicijative za regionalnim grupiranjem javljaju se kao obrnuti proces od globalizacije i teže stvaranju čvršćih veza na regionalnom planu, povoljnijih uvjeta za razvoj u regionalnom okruženju, te jačanju pregovaračkih pozicija i konkurentskog položaja grupa zemalja na svjetskom tržištu (...) Proces regionalizacije odvija se na dvije razine, na razini nacionalnih država i na razini regija unutar pojedinih država (...) Međusobno se regionalno povezuju zemlje sličnih interesa « (Samardžija, 1994: 6). Prije svega treba objasniti razliku između regionalnih organizacija i regionalnih inicijativa. Regionalne su organizacije pravni subjekt te se temelje na međunarodnom sporazumu, poveljama i konvencijama kao obvezujućim međunarodnopravnim aktima, dok regionalne inicijative nemaju pravnu osobnost te se temelje na deklaracijama i običnim političkim nomenklaturama (ministarstvo/premijer ih samo usvaja). Obje mogu imati članarine, ali samo regionalne organizacije imaju tajništva. Svaka regionalna inicijativa teži da postane regionalna organizacija. ${ }^{1}$ Sama bit Europske unije jest regionalna suradnja, tj. da različiti ljudi sjedaju za isti stol i rješavaju probleme - na principu pomirenja Njemačke i Francuske proizašlog iz Elizejskog ugovora $1963 .^{2} \mathrm{U}$ tom se razdoblju radilo o izgradnji porušene

Razgovor s voditeljicom Odjela za regionalne inicijative Ministarstva vanjskih i europskih poslova RH (25. svibnja 2012.).

2 Model francusko-njemačkog pomirenja bio je model za suradnju mnogih zemalja koje su imale nesuglasice i neriješena pitanja, npr. Rumunjska i Mađarska oko pitanja manjina i teritorijalnih pretenzija (prema dokumentu ds/2-13 od 15.veljače 1996. Ministarstva vanjskih i europskih poslova i Veleposlanstva Republike Hrvatske u Bukureštu). 
Europe, a model je bio temelj ideje kojom su se Nijemci našli pozvanima da rješavaju situaciju na jugoistoku Europe. Usvajanjem Pakta o stabilnosti za jugoistočnu Europu 1999. počinje hiperprodukcija regionalne suradnje, tj. nastaju brojne regionalne organizacije i inicijative. Uspjeh regionalnih organizacija uglavnom je na političkom polju, a ostala polja suradnje odvijaju se bilateralno između država sudionica pojedinih organizacija. Stoga možemo reći da su regionalne organizacije multilateralne (zbog brojnog članstva), ali većina pitanja rješava se bilateralno među državama članicama.

Regionalna inicijativa za migracije, azil i izbjeglice (MARRI) utemeljena je 2003. u okviru Pakta stabilnosti za jugoistočnu Europu. Nastala je spajanjem Inicijative za regionalni povratak raseljenih osoba (RRI) s Inicijativom za migracije i azil (MAI). Od srpnja 2004. ta je Inicijativa pod regionalnim upravom. Bavi se pitanjima upravljanja migracijama na Zapadnom Balkanu, promiče bližu regionalnu suradnju te ima sveobuhvatan pristup pitanjima migracija, azila i upravljanja granicama prema međunarodnim i europskim standardima. MARRI je važni dio procesa integriranja u Europsku uniju. Zemlje koje sudjeluju u MARRI-ju su Albanija, Bosna i Hercegovina, Hrvatska, Crna Gora, Makedonija i Srbija. Ulaskom Hrvatske u EU 2013. umjesto nje je novom članicom u MARRI-ju postalo Kosovo.

Područja djelovanja MARRI-ja odnose se na migraciju, azil, readmisiju, ${ }^{3}$ upravljanje granicama, viznu politiku te integraciju ili povratak izbjeglica. Ta inicijativa funkcionira kroz dva mehanizama djelovanja - MARRI Regionalni forum i MARRI Regionalni centar u Skopju. MARRI regionalni forum pruža politički okvir i podršku Inicijativi te zasjeda dvaput godišnje. MARRI regionalni centar u Skopju operativno je tijelo Inicijative. Formalno je osnovan potpisivanjem Memoranduma o razumijevanju 2. srpnja 2004. u Tirani (Albanija) i Sporazuma o sjedištu Regionalnog centra 15. studenog 2004. u istome gradu. Centar je počeo s radom 18. studenog 2004. On je podrška provođenju odluka donesenih na Regionalnom forumu. Sjedište mu je u Skopju (Makedonija) i predstavlja vezu između zemlje predsjedavajućega Regionalnog foruma i država članica MARRI-ja. U centru su zastupljene, preko predstavnika, sve članice Foruma. Ravnatelj centra bira se na mandat od tri godine. Osim ta dva mehanizma djelovanja MARRI ima i Upravni odbor, koji čine države Zapadnog Balkana, ostale članice Pakta stabilnosti, Europske komisije, Organizacije za europsku sigurnost i suradnju (OSCE), UN-ova agencija za izbjeglice (UNHCR), Međunarodna organizacija za migracije (IOM), Međunarodni centar za razvijanje politike migra-

Readmisija znači povratak osoba koje neosnovano borave na teritoriju neke države u zemlje porijekla. 
cija (ICMPD) te razne nevladine organizacije. Odbor se sastaje dva do tri puta godišnje. ${ }^{4}$ Službeni je jezik MARRI-ja engleski. Inicijativom predsjeda svaka država članica na rok od jedne godine, pri čemu se donose prioriteti predsjedanja svake pojedine države kao glavni dokumenti organizacije. ${ }^{5}$ MARRI-jem upravljaju vlade šest država članica, koje se susreću dvaput godišnje na MARRI Regionalnom forumu. Prvi MARRI Regionalni forum o azilu, migracijama i održivom povratku u okviru Procesa suradnje u Jugoistočnoj Europi (South-East European Cooperation Process - SEECP) održan je 5. travnja 2004. u Herceg Novom (Crna Gora), gdje je odlučeno da će se uspostaviti Regionalni centar u Skopju.

Temeljni su dokumenti MARRI-ja: Memorandum o razumijevanju - utemeljenje regionalnog foruma za migracije, azil i povratak izbjeglica (2004.), Zajednička izjava - deklaracija iz Herceg Novog (2004.), Sporazum o zemlji domaćinu (Host agreement), MARRI deklaracije - Podgorica (2016.), Skopje (2015.), Cavtat (2014.), Beograd (2012.), Drač (2011.), Budva (2010.), Ohrid (2009.), Zagreb (2008.), Sarajevo (2007.), Beograd (2006.) i Tirana (2005.), Strategija MARRI 2014. - 2016. te službeni dokument MARRI RC. ${ }^{6}$

Moto MARRI-ja jest: »MARRI RC - katalizator za Zapadni Balkan i odgovor na izazove migracija, azila i izbjeglica « (»MARRI RC - the catalyst of Western Balkans response to migration, asylum and refugees challenges«).

Neki od projekata MARRI-ja:

- 2007. MARRI migracijski plan

- 2007. Pregled viznog režima

- 2008. MARRI MS vizna statistika

- 2009. MARRI MS vizni režim

- 2012. Migracije za razvoj Zapadnog Balkana

- 2012. Zajednički sveobuhvatan pristup u uspostavljanu suradnje između MARRI-ja i Udruženja šefova policije jugoistočne Europe (SEPCA)

- 2012. MARRI migracijski plan

- 2013. - 2016. BORDIARPOL I. ${ }^{7}$

Podaci dostupni sa službenoj internetskog stranici inicijative: www.marri-rc.org.

5 Npr. Prioriteti MARRI predsjedništva BIH 2012. - 2013., Prioriteti Albanije 2010. - 2011., Prioriteti Crne Gore 2009. - 2010., Prioriteti Makedonije 2008. - 2009., Prioriteti predsjedanja Hrvatske 2007. - 2008. i prioriteti predsjedanja BIH 2006. - 2007.

6 Podaci dostupni sa službenoj internetskog stranici inicijative: www.marri-rc.org.

7 MARRI projekt vezan uz suradnju graničnih policija na aerodromima (prema: www.m.avaz.ba). Frontex je europska agencija za upravljanje operativnom suradnjom na 
- 2015. - 2016. Unapređivanje postupaka za utvrđivanje identiteta ilegalnih migranata u MARRI regiji

- 2016. Međunarodna konferencija MARRI - Zajedničko djelovanje u upravljanju migracijama, te jačanje koordinacije na centralnoj i lokalnoj razini

- 2016. - 2018. BORDIARPOL II. (trenutačni projekt) - suradnja između graničnih policija u jugoistočnoj Europi. Švicarski ured za migracije dao je donaciju ovom projektu. U provedbi projektnih aktivnosti surađuje se s DCAF Frontexom. ${ }^{8}$

Jedan je od projekata MARRI-ja i »Podrška suradnje između graničnih policija na zračnim lukama i jugoistočnoj Europi«, koji je pokrenut 1. siječnja 2013. i trajao tri godine. On je bio nastavak dvaju sličnih projekata također o suradnji graničnih policija. Opći je cilj projekta pomoći zemljama jugoistočne Europe da se učinkovitije nose s neregularnim imigracijama i bore protiv terorizma i kriminala te da se održi visoka razina sigurnosti na trajnoj osnovi. Specifični su ciljevi projekta učinkovita međuregionalna suradnja i razmjena informacija, uvid u aktualno stanje u zračnom prometu, generiranje informacija, poboljšanje kapaciteta granične policije na međunarodnim zračnim lukama, zaštićene web-stranice, godišnji susreti i organizacija zajedničkih treninga. Korisnici su ovoga projekta granične policije iz zemalja jugoistočne Europe - Albanija, Bosna i Hercegovina, Bugarska, Hrvatska, Makedonija, Moldavska Republika, Crna Gora, Rumunjska i Srbija. Partneri u projektu su: Interpol, Europol, Frontex (agencija za europsku graničnu i obalnu stražu), švicarsko tajništvo za migracije (FOM), Policijska suradnja za jugoistočnu Europu (PCC SEE), Udruženje šefova policije jugoistočne Europe (SEPCA) i Centar za provedbu zakona na jugoistoku Europe (SELEC). Projekt financira Švicarska Konfederacija, a sufinancira MARRI.

Jedan od najnovijih izazova s kojima se još uvijek suočava MARRI jest izbjeglička/migrantska »kriza « 2015./2016., kada su izbjeglice iz ratom pogođene Sirije, ali i iz Iraka, Pakistana i Afganistana, prelazile granice Zapadnog Balkana na svom putu prema Austriji, Njemačkoj i skandinavskim zemljama. MARRI je tijekom te krize radio na osiguravanju hrane, skloništa za izbjeglice i svih osnovnih potreba ljudi, na načelu humanosti i solidarnosti. Tako je suradnja balkanskih zemalja postala važna za regionalnu sigur-

vanjskim granicama država članica EU-a. Sjedište mu je u Varšavi (Poljska). Osnovalo ga je 3. listopada 2005. Vijeće Europske unije (https://frontex.europa.eu/).

8 Podaci o projektima inicijative preuzeti su s internetske stranice: www.marri-rc.org.mk. 
nost i stabilnost. Čelni ljudi MARRI-ja priznali su kako nisu bili spremni za migracije takvih razmjera, te su zajedničke strategije kako se nositi s tolikim brojem izbjeglica razrađivane u hodu (Hart, 2015). ${ }^{9}$

\section{HRVATSKA I REGIONALNA INICIJATIVA ZA MIGRACIJE, AZIL I IZBJEGLICE}

Hrvatska je članica MARRI-ja od njezina utemeljenja 2003. Prvo predsjedanje MARRI Regionalnim forumom Hrvatska je preuzela 26. travnja 2007. na rok od jedne godine (travanj 2007. - travanj 2008.). Tijekom svoga jednogodišnjeg predsjedanja Hrvatska je uložila napore u jačanje i promicanje MARRI-ja te osobito u razvoj koncepta regionalnog vlasništva. Predsjedništvo je radilo na pokretanju i nadzoru te davalo smjernice za dovršavanje projekata, za programe i sastanke radnih skupina i stručnjaka te za dva MARRI Regionalna foruma na razini političkih direktora u studenome 2007. i travnju 2008. Pozornost je bila usmjerena na pridavanje važnosti kontinuiranoj suradnji između država članica MARRI-ja te promicanje sigurnosti i stabilnosti u regiji.

Program djelovanja Hrvatske kao predsjedatelja MARRI-ja ogledao se u ovim ciljevima: 1) udruživanje zemalja u regiji za što lakše približavanje strukturama Europske unije, 2) jačanje regionalne suradnje i podizanje svijesti u pitanju migracija, 3) izbjegavanje preklapanja aktivnosti s drugim regionalnim organizacijama, 4) održavanje seminara i kontakata s ministarstvima vanjskih poslova zemalja regije, 5) bolja suradnja s drugim organizacijama i s Europskom unijom, 6) razmjena informacija s Europolom i Frontexom, 7) borba protiv neregularne migracije, krijumčarenja migranata i trgovine ljudima, 8) prekogranična suradnja i 9) borba protiv organiziranog kriminala. ${ }^{10}$ Svoje drugo predsjedanje organizacijom MARRI Hrvatska je preuzela 25. srpnja 2013. od Bosne i Hercegovine. Nakon toga Hrvatska se kao nova članica Europske unije povukla iz tog formata suradnje.

9 U tekstu se upućuje na intervju s ravnateljicom MARRI-RC Tamarom Mugosom (Crna Gora) za Wall Street International, 12. studenoga 2015., (preuzeto sa: www.marri-rc.org. $\mathrm{mk} /$ ?s=migrants+from+Syria). Cijeli intervju može se pročitati na internetskoj stranici www.wsimag.com/economy-and-politics/1852-cooperation-among-balkan-states.

10 Podaci dostupni na internetskoj stranici Ministarstva vanjskih i europskih poslova RH: www.mvep.hr. 


\section{LITERATURA}

Hart, C. (2015). Cooperation among Balkan States: A Key Ingredient for EU Integration, Wall Street International, 12 November 2015, www.wsimag.com/economy-andpolitics/1852-cooperation-among-balkan-states (19.10.2017.).

Samardžija, V. (1994). Europska unija i Hrvatska: putevi povezivanja i suradnje. Zagreb: IRMO.

Tuđman, M. i Ljubičić, M. (ur.) (2007). Hrvatska i zapadni Balkan: rasprave o suverenitetu, nacionalnom identitetu i vanjskoj politici. Zagreb: UHIP. 